\title{
Waste Water Remediation Using Nanotechnology-A Review
}

\author{
Keerthana Vedhantham ${ }^{1 \mathbb{D}}$, Agnishwar Girigoswami ${ }^{1 \mathbb{D}}$, Harini $\mathbf{A}^{1}$, Koyeli Girigoswami ${ }^{1, *}$ : \\ 1 Medical Bionanotechnology, Faculty of Allied Health Sciences, Chettinad Hospital and Research Institute, Chettinad \\ Academy of Research and Education, Chettinad Health City, Kelambakkam, 603103, Tamilnadu, India \\ * Correspondence: koyelig@gmail.com (K.G.);
}

Scopus Author ID 23060318900

Received: 12.08.2021; Revised: 18.09.2021; Accepted: 22.09.2021; Published: 3.10.2021

\begin{abstract}
Textile azo dyes are used for coloring fabrics that are potentially carcinogenic and mutagenic chemicals. It is disposed of as industrial effluents into the environment, causing major hazardous impacts on the aquatic ecosystem, and also gets deposited onto the soil for a prolonged period. Several conventional methods previously applied for eliminating these dyes are limited for their low efficiency and high cost. To overcome those issues, various novel semiconductor photocatalysts, nano adsorbents, nanocomposites, and other nanostructures were employed for achieving maximum efficacy at a low cost. In this review, we shall discuss the different nanostructures and nanocomposites used for textile dye remediation.
\end{abstract}

Keywords: textile dye removal; nanotechnology; nano adsorbents; natural bioremediation agents; nanocomposites.

(C) 2021 by the authors. This article is an open-access article distributed under the terms and conditions of the Creative Commons Attribution (CC BY) license (https://creativecommons.org/licenses/by/4.0/).

\section{Introduction}

Rapid industrialization has led to the growth of mankind, with urbanization compromising the fine balance between the health of flora and fauna and the harmful environmental pollutants. Human health is also compromised, being a part of this imbalanced ecosystem [1]. Compared to the different pollutions, water pollution has posed serious threats to living beings because the effluents from different dye industries and tanneries meet the water bodies for contamination. Pigment manufacturing, cosmetic, food, printing, textile, leather, dyeing, etc., are the major contributors to water pollution [2, 3]. Previous studies showed that nearly $15 \%$ of the total dyes used in textile industries stay unreacted and majorly contribute to the affluents [4]. Azo dyes were also synthesized and microencapsulated to prepare nano inks which are used for textile printing [5]. The synthetic dyes from different industries contribute significantly to both water and soil contamination. These cannot be removed by the ordinary treatment process, thereby making them remain in the environment for a long time [6]. The presence of these dyes has an adverse effect on living beings, including humans and animals, eventually causing liver and kidney damage, skin irritation, nausea, vomiting, irritation of the gastrointestinal tract, etc. The effect is also extrapolated in plants where these dyes inhibit seed germination, change the root and shoot length, and inhibit microbial activity $[7,8]$. 


\section{Bioremediation}

Bioremediation is when pollutants like chemicals, dyes, industrial effluents, biological wastes, etc., are removed using different physicochemical methods or microbes from soil or water. By utilizing the living organisms or microorganisms, the pollutants and contaminants are reduced to a lower toxic form, and bioremediation is mediated. The principle behind it is the capacity of a microorganism or any biocompatible catalyst to degrade the hydrocarbons present in the contaminant to simpler forms that can act as a nutrient source by the microorganisms present in the contaminated soil or water. After degrading organic components, the released products are water, carbon dioxide, and some more inorganic compounds. By utilizing these degraded products, safer components are released to the environment. The plants can also contribute to the biodegradation of hydrocarbons [9].

There are two types of bioremediation strategies:

\subsection{In Situ bioremediation.}

In this type of bioremediation, the soil contaminations due to oil spills are taken care of. The method is cost-effective and conducts the bioremediation without disturbing the surrounding area around the site of contamination. The depth in soil which is reached for conducting the bioremediation process is nearly $30-60 \mathrm{~cm}$ in depth. The limitation in depth is because only up to this depth can the aid of the microorganisms in degrading the pollutants.

\subsubsection{Bioventing.}

Bioventing is a kind of in situ method for bioremediation in which air is supplied at a very low rate of flow that can provide oxygen and nutrients through wells to the microorganisms present in the contaminated site. This will stimulate the growth of the microorganisms, and the bioremediation is executed effectively. The only thing that should be ensured is that there is no volatilization of the spilled contaminant through the wells, and their further spread is avoided. This method is effective for simple hydrocarbons.

\subsubsection{In situ biodegradation.}

This is another process of in situ bioremediation in which nutrients and oxygen are enriched to the soil using an aqueous solution that can circulate within the contaminated soil. The aqueous solution is composed of water-containing nutrients, acceptors of electrons, and oxygen which can stimulate the growth of microorganisms. This kind of bioremediation is used for the treatment of soil and groundwater.

\subsubsection{Biosparging.}

Biosparging is another method of in situ bioremediation. This method infuses air under low pressure into the water table present below, thereby increasing the oxygen percentage available to the microorganisms. This increases the biodegradation capacity of the microorganisms by mixing the oxygen in the saturated zone and increases the interaction between the groundwater and soil. The air injectors designed for this purpose are easy to handle and install, making the process highly feasible. The design flexibility also aids for the injector implementation in a large number of contaminated sites. 


\subsection{Ex-situ bioremediation.}

In this bioremediation method, the contaminated soil is excavated and placed in an elevated stage above the area of ground treatment. This soil is aerated and processed to degrade organic contaminants by the microbes that are present indigenously. In case of contaminated water, the water is drawn outside the contaminated area, followed by decontamination processes using either microbes or physicochemical agents, and replenished back to the source.

\subsubsection{Biopiles.}

Biopiles are one of the methods of ex situ bioremediation which combines both landfarming and composting. The chambers are engineered in compost piles that are wellaerated. This method is superior to the landfarming method as it can control the contamination to spread through leaching and volatilization. The spillage of hydrocarbon pollutants, usually the petroleum products on the surface, contaminates the soil and is remediated using this technique. Landfarming and composting are the other two methods apart from biopiles for $e x$ situ bioremediation.

\subsubsection{Bioreactors.}

Bioreactors are another type of ex-situ bioremediation set up for the treatment of hydrocarbon pollutants. The slurry reactors or aqueous reactors can be used to treat contamination in soil or water. In a huge contaminant vessel, the contaminants are poured, and with the help of different apparatus, they are mixed in a three-phase system- solid, liquid, and gas. This mixing-up procedure not only helps the biodegradation of pollutants but also increases the biomass-containing microorganisms. This technique has a limitation that there should be some pre-treatment done to the water or soil before adding them to the bioreactors [10]. Although both the in situ and ex situ methods used for bioremediation are highly effective, the bioreactors have a higher rate and extent of bioremediation due to their safety. There is no volatilization or leaching of contaminants from the chambers of bioreactors, and the conditions are more controllable and predictable to yield effective results.

\section{Textile Dyes}

Textile dyes are used for different color types of textiles like cotton, polyester, blended cotton, synthetic cloth materials, etc. These are synthetic chemical compounds that have aromatic structures, resistant to biodegradation because of their xenobiotic nature. The toxicity of dyes is exerted into the aquatic system, both flora and fauna, because the dyes can perturb the penetration of light, thereby obstructing the photosynthesis process of the aquatic system. The dyes used in the textile industry are synthetic in most cases which are derived from mainly two sources, petroleum-based intermediates, and coal tar. The common forms of these dyes available on the market are powders, pastes, granules, or liquid dispersions. The dyes are regularly used for dyeing new kinds of fabrics and detergents using advanced dyeing machines, posing some serious threats due to environmental exposure to such dyes.

\section{Types of Textile Dyes}

The classification of all the commercial textile dyes by their generic name and the chemical constitution has been done by the Color Index (C.I.), a journal published by the 
Society of Dyers and Colorists (United Kingdom) in association with the American Association of Textile Chemists and Colorists (AATC). However, according to general dye chemistry classification, textile dyestuffs can be grouped into the following 12 categories; Acid Dyes, Direct Dyes, Azoic Dyes, Disperse Dyes, Sulfur Dyes, Reactive Dyes, Basic Dyes, Oxidation Dyes, Mordant Dyes (Chrome Dyes), Vat Dyes, Optical/Fluorescent Brightener and Solvent Dyes. The dyes have different extents of fixing to the fiber during the dyeing process. The reactive dye which is used for dyeing cotton has the minimum rate of fixation. More than half of the textile-fiber market is dominated by cotton, which has a minimum rate of dye fixation, resulting in environmental threats posed due to colored effluents from these industries [11]. Sulphonated vinyl reactive dyes (azo chromophore group $\mathrm{N}=\mathrm{N}$ ) are the major constituent of dyes used in the textile industry, contributing about $60 \%$ of the total dyes [12]. These compounds are water-soluble and are found in high concentrations in the discharged wastewater (nearly up to 50\%), indicating the dye percentage which does not fix in the textile fibers [13].

\section{Dye Degradation}

During the degradation process of dye, it is oxidized into $\mathrm{CO}_{2}, \mathrm{H}_{2} \mathrm{O}$, and some minerals. Textile industries release the unused dyes in the dyeing process as wastewater into the water bodies or environment. The modern method for dye bleaching or photocatalytic degradation is heterogeneous photocatalysis, in which the photogenerated electrons of sulfides and oxides at the semiconductor surface of the valence band get transferred to the conduction band. As a result, hydroxide radicals and superoxide anions were produced from the interaction between excitons and water or oxygen that has high potential in degrading several molecules such as textile dyes using potential oxidizing power. Moreover, these decontamination reactions are termed as Advanced Oxidation Process (AOP), involving reactive oxygen species in several ways (e.g., Fenton processes) [14]. Some researchers have shown the degradation of the azo dye methyl orange (MO) in stimulated wastewater using different nanomaterials that acted as a photocatalyst under visible light. Titanium dioxide $\left(\mathrm{TiO}_{2}\right)$, graphene oxide $(\mathrm{GO})$, and zinc oxide $(\mathrm{ZnO})$ were synthesized, followed by characterization, and utilized for the MO dye reduction [15].

\section{Nanotechnological Approaches for Remediation of Harmful Dyes}

The nanotechnological approach is considered a single complete package that combines several procedural phases of conventional methods and minimizes the cost invested in wastewater purification plants. Nowadays, nanotechnology has been applied in different areas of food toxin detection, nanosensors, nanoneutraceuticals, targeted drug delivery, imaging, theranostics, and photodynamic inactivation of microorganisms [16-29]. In industries, almost 10,000 types of dyes are used for coloring purposes. Dye effluents invariably affect aquatic and human life when mixed into water bodies because of their toxic effects, bioaccumulation, and persistence. These contaminants can be remediated using various materials and techniques. The application of multi-dimensional and multi-functional nanomaterials was more simplified, economical, and advantageous over other procedures [30]. The importance of nanotechnology in wastewater treatment has been emphasized in recent years. Though there are different aspects of approaches taken in remediation, the sequential procedure follows: Sensing and 
targeting, adsorption of dye onto nano sorbent, photocatalytic redox reaction using nanocatalyst, decomposition, decontamination, and filtration of purified water [31].

The major concern was the gap between in-situ and ex-situ applications that affected the possibility and desired outcome in large-scale mitigation of pollutants in environmental settings. Most of the studies were conducted only in laboratories and for in-situ detoxification. There is very less knowledge on how to handle nanomaterials and how they are carried along with a dynamic ecosystem. So, the need for standard guidelines and regulations is important to reduce the adverse effects of ex-situ implementation. However, the challenges involved in the commercialization of nanomaterials should be addressed. Using the twelve principles of green chemistry and by adopting green nanotechnology methods, eco-friendly products can be designed. These include the prevention of waste, effective integration of every resource, production, and usage of less or non-toxic materials, making safe substances with potential function, use of possibly harmless supporting materials and solvents only if necessary, less energy consumption with adaptable universal synthesis techniques, designing reusable, recyclable, renewable material sources, minimizing unwanted by-products, stoichiometric based selective use of catalysts, end products should be ecological and biodegradable, simultaneous analysis of preparation process to avoid harmful substance formation and choosing good substances for overall designing to prevent accidental hazards [32].

In order to overcome the different issues of other types of textile remediation methods like low stability, low biocompatibility, and high cost, nanostructures are nowadays used for the azo dyes and other types of dyes remediation.

\section{Nanocomposites}

The different graphene and titanium dioxide-based nanostructures used for bioremediation are given in Table 1.

Table 1. The different types of nanocomposites prepared using graphene and Titanium oxide utilized for wastewater remediation.

\begin{tabular}{|c|c|c|c|}
\hline S No. & Nanocomposite used & Finding of study & Reference \\
\hline 1. & $\begin{array}{l}\mathrm{ZnO} / \mathrm{TiO}_{2} \text { anchored on reduced } \\
\text { graphene oxide (rGO) ternary } \\
\text { nanocomposite heterojunction }\end{array}$ & $\begin{array}{l}\text { The nanocomposite of } \mathrm{rGO}, \mathrm{ZnO} \text {, and } \mathrm{TiO}_{2} \text { was used for } \\
\text { the decontamination of phenol in an aqueous solution. }\end{array}$ & {$[33]$} \\
\hline 2. & $\begin{array}{l}\text { Graphene-based- } \mathrm{TiO}_{2} \\
\text { nanocomposites }\end{array}$ & $\begin{array}{l}\text { The present short review describes the recent advances in } \\
\mathrm{TiO}_{2} \text { photocatalyst } \\
\text { coupling with graphene materials to extend the light } \\
\text { absorption of } \mathrm{TiO}_{2} \text { from UV } \\
\text { wavelengths into the visible region, focusing on recent } \\
\text { progress in the design and applications in the } \\
\text { photocatalytic degradation of synthetic dyes }\end{array}$ & {$[34]$} \\
\hline 3. & $\begin{array}{l}\mathrm{TiO}_{2} / \mathrm{G} \text { and } \mathrm{TiO}_{2} / \mathrm{GO} \\
\text { nanocomposites }\end{array}$ & $\begin{array}{l}\text { This review focuses on the recent } \\
\text { development in the chemistry of } \mathrm{TiO}_{2} / \mathrm{G} \text { and } \mathrm{TiO}_{2} / \mathrm{GO} \\
\text { nanocomposites. It addresses the mechanistic } \\
\text { fundamentals, briefly, of } \mathrm{TiO}_{2} \text { and } \mathrm{TiO}_{2} / \mathrm{G} \text { and } \mathrm{TiO}_{2} / \mathrm{GO} \\
\text { photocatalysts, the various synthesis } \\
\text { strategies for preparing } \mathrm{TiO}_{2} / \mathrm{G} \text { and } \mathrm{TiO}_{2} / \mathrm{GO} \\
\text { nanocomposites, and the } \mathrm{different} \text { characterization } \\
\text { techniques used to study } \mathrm{TiO}_{2} / \mathrm{G} \text { and } \mathrm{TiO}_{2} / \mathrm{GO} \\
\text { nanocomposites. Some applications of the use of } \mathrm{TiO}_{2} / \mathrm{G} \\
\text { and } \mathrm{TiO}_{2} / \mathrm{GO} \text { nanocomposites in water decontamination } \\
\text { are included. }\end{array}$ & [35] \\
\hline 4. & GO coated with $\mathrm{TiO}_{2}$ & $\begin{array}{l}\text { Visible light responsive graphene oxide (GO) nano titania } \\
\text { composite was synthesized, and its photocatalytic activity } \\
\text { was investigated to degrade Eosin Yellow (EY). }\end{array}$ & [36] \\
\hline 5. & $\begin{array}{l}\left(\mathrm{GO}-\mathrm{TiO}_{2}-\mathrm{ZnO}\right) \\
\text { nanocomposite }\end{array}$ & $\begin{array}{l}\text { Degradation of an azo dye, methyl orange (MO), was } \\
\text { tested in simulated wastewater with the synthesized } \\
\text { nanocomposite using visible light }\end{array}$ & [37] \\
\hline \multicolumn{4}{|c|}{ https://biointerfaceresearch.com/ } \\
\hline
\end{tabular}




\begin{tabular}{|c|c|c|c|}
\hline S No. & Nanocomposite used & Finding of study & Reference \\
\hline 6. & $\begin{array}{l}\mathrm{TiO}_{2}-\mathrm{Pt} \text { nanoparticles }(\mathrm{TPt}) \\
\mathrm{TiO}_{2}-\mathrm{Pt} / \mathrm{graphene} \text { oxide }(\mathrm{TPt}- \\
\mathrm{GO} \text { ) and } \mathrm{TiO}_{2-} \\
\text { Pt/reduced graphene oxide } \\
\text { (TPt-rGO) composites }\end{array}$ & $\begin{array}{l}\text { The photocatalytic degradation of azo dyes with different } \\
\text { structures (amaranth, sunset yellow, and tartrazine) using } \\
\mathrm{TiO}_{2}-\mathrm{Pt} \text { nanoparticles }(\mathrm{TPt}), \mathrm{TiO}_{2}-\mathrm{Pt} / \text { graphene oxide (TPt- } \\
\mathrm{GO} \text { ), and } \mathrm{TiO}_{2}-\mathrm{Pt} / \mathrm{reduced} \text { graphene oxide (TPt-rGO) } \\
\text { composites were investigated in the presence of UV and } \\
\text { natural sunlight irradiation. }\end{array}$ & {$[38]$} \\
\hline 7. & $\begin{array}{l}\text { Composites of graphene } \\
\text { oxide and } \mathrm{TiO}_{2}\left(\mathrm{GO}-\mathrm{TiO}_{2}\right) \\
\text { sensitized with a natural dye } \\
\text { extracted from a Colombian } \\
\text { source (Bactris guineensis) }\end{array}$ & $\begin{array}{l}\text { The } \mathrm{TiO}_{2} \text {-GO nanopowder was coated to a thin film and } \\
\text { heated at high temperature for processing with a natural } \\
\text { dye to yield a final product which was used for } \\
\text { photocatalysis of MB dye. }\end{array}$ & [39] \\
\hline 8. & $\begin{array}{l}\text { reduced graphene oxide (rGO)- } \\
\mathrm{TiO}_{2} \text { hybrid nanocrystals }\end{array}$ & $\begin{array}{l}\text { The prepared } \mathrm{rGO}-\mathrm{TiO}_{2} \text { nanocomposites exhibited } \\
\text { superior photocatalytic activity }\left(0.135 \mu \mathrm{mol} \mathrm{g}_{\mathrm{cat}}{ }^{-1} \mathrm{~h}^{-1}\right) \text { in } \\
\text { reducing } \mathrm{CO}_{2} \text { over graphite oxide and pure anatase. }\end{array}$ & [40] \\
\hline
\end{tabular}

\section{Nano-Adsorbents}

Nano adsorbents are nanoparticles having greater adsorption and desorption property, and they help in achieving effective remediation of harmful textile dyes. It can be synthesized from both inorganic and organic sources, such as metals and non-metals. For efficient adsorption of dye molecules and degradation into less or non-toxic forms, the nano- adsorbent has to be manipulated at the inner surface and outer functionalization. The rate of adsorption mechanism of textile dye effluents depends on various physicochemical properties, including small size, shape, incubation time, chemical composition, surface binding energy, temperature, crystal structure, location of atoms, $\mathrm{pH}$, adsorption potential, solubility, chemical reactivity, agglomeration, the ratio between surface area and volume [41, 42]. The adsorption-desorption distribution coefficient $\left(\mathrm{K}_{\mathrm{d}}\right)$ plays a significant role in the overall process.

\section{Nanocatalysts}

Nanocatalysts are potent catalytic materials utilized to degrade fabric dyes and other organic contaminants present in wastewater. The photocatalytic reduction and chemical oxidation degradation require natural light sources, including ultra-violet (UV), visible light, or artificial illumination. Electrocatalysts, Photocatalysts, and Fenton-based nanocatalysts are the major types applied for pollutant remediation. Among various nanocatalysts, the metal oxide and semiconductor types from inorganic sources were beneficial for treating water and contaminants removal. It had specific advantages like rapid remediation, effective modification capability, good photocatalytic ability, and selective to recalcitrant pollutants. The disadvantages are difficulty in recycling and expensive nanoparticles. Zinc oxide ( $\mathrm{ZnO}$ ) was one of the best nanocatalysts for dye decolorization due to its large bandgap of $3.2 \mathrm{eV}$ and antimicrobial activity against contaminants similar to Titanium dioxide $\left(\mathrm{TiO}_{2}\right)$ nanoparticles. Bandgap reduction can be achieved by anion (Nitrogen, Sulphur, and Carbon) doping at interstitial and substitutional locations of nanoparticles lattices. This was necessary to promote visible light absorption and photocatalytic redox reaction. The remediation mechanism follows the following steps: Light irradiation at nanocatalysts; excited electrons jump from valence to conduction band; formation of positive holes; transfer of holes among nanoparticles and organic molecules; production of hydroxyl radicals by reacting with oxygen and water molecules; reaction between positive holes and oxygen forms singlet oxygen; free electrons with oxygen produces superoxide radical anions; at last, the holes acts on pollutants adsorbed on the surface and in water was degraded by the most reactive hydroxyl radicals $[41,42]$.

\section{Different Types of Catalytic Nano Adsorbents for Dyes}


Nano adsorbents can be classified as metallic, non-metallic, oxide-based, carbon-based, magnetic; non-magnetic based, ceramic, polymeric, composites, zeolites [41, 42], semiconductors [43], nanoclays, nanofiltration membranes, enzyme incorporated nanotechnology [44], microbial nanotechnology [45], and other novel bionanomaterials.

In a study, lignin peroxidase was produced from Alcaligenes aquatilis DB8 and was purified. The lignin peroxidase was immobilized by entrapping it on $\mathrm{Ca}$-alginate and chitosan through adsorption and a crosslinker. This was further successfully used to reduce the harmful dye malachite green [46]. The oxide-based nano adsorbents are iron oxide, zinc oxide, magnesium oxide, titanium dioxide, manganese oxide and were used in wastewater treatment for dye removal. The natural sources and simplified synthesis of nano adsorbents make them very cost-effective in many applications.

\subsection{Metal nano adsorbents.}

The different kinds of green synthesized nanoparticles that are used for the remediation of wastewater have been discussed previously [47]. We have mentioned a few important nanoparticles that are used as nano adsorbents.

\subsubsection{Silver and gold nanoparticles synthesized through green routes.}

Surprisingly, the Methylene Blue (MB) dye was completely decolorized in 10 min by the outstanding catalytic effects of Gmelina arborea fruit extracts combined synthesis of Silver (Ag) nanoparticles. The alkaline $\mathrm{pH}$-dependent Silver (Ag) nanoparticles prepared in the extract of Morinda tinctoria leaves having 79-96 nm size removed 95.3\% Methylene Blue dye (MB), showing an absorption peak of $660 \mathrm{~nm}$ within 72 hours under sunlight exposure. Biogenic production from leaf extracts of Alpinia nigra combined Gold ( $\mathrm{Au}$ ) nanoparticles demonstrated decolorization under sunlight after $120 \mathrm{~min}$ in both Rhodamine B (RhB) and Methyl Orange (MO) dyes with photocatalytic degradation potential of $87.64 \%$ and $83.25 \%$, respectively. In addition, plant extracts of Stemona tuberosa Lour mediated preparation of Gold $(\mathrm{Au})$ and Silver (Ag) nanoparticles completely removed Methyl Red (MR), Methylene Blue (MB), and Methyl Orange (MO) dyes with the help of sodium borohydride $\left(\mathrm{NaBH}_{4}\right)$ [48]. Organic Methylene Blue (MB) dye was remediated using catalytic reduction by biogenic Penicilliun oxalium fungus supported silver nanoparticles (Au-NPs), and Fammulina velutipes synthesized biomatrix Silver (Ag-NPs) nanoparticles [43]. Silver nanoparticles were synthesized using Artemisia annua L leaf extract, which exhibited good antimicrobial activity and antioxidant activity. These green synthesized nanoparticles also showed lemon yellow and orange-red food dye remediation properties [49].

\subsection{Metal oxide nano adsorbents.}

\subsubsection{Tin oxide nanoparticles.}

The tin oxide nanoparticles $\left(\mathrm{SnO}_{2}\right)$ with an average size of $8.4 \mathrm{~nm}$ were prepared using the leaf extracts of Piper betle, which could degrade 97.17\% of Reactive Yellow 186 (RY186) industrial dye using sunlight mediated catalysis [50]. Sugarcane juice biomolecules aided the synthesis of 2.5 to $4.5 \mathrm{~nm}$-sized Tin oxide quantum dots $\left(\mathrm{SnO}_{2} \mathrm{QDs}\right)$, which showed solar light facilitated photocatalytic dye degradation. The absorption peaks of Methylene Blue (MB) dye at $663 \mathrm{~nm}$ and Rose Bengal (RB) dye at $540 \mathrm{~nm}$ indicated that the dyes were decolorized within 
$240 \mathrm{~min}$ and $180 \mathrm{~min}$, respectively [51]. The $\mathrm{SnO}_{2}$ nanoparticles prepared in ascorbic acid degraded Methylene Blue (MB) dye and even while using the same material for four repeated usages showing unvaried efficiency [52].

\subsubsection{Iron oxide nanoparticles.}

Generally, nanoscale iron particles and their types are highly validated for their in-situ remediation capacity and promising size-dependent synthesis of 10-100 nm using Fe (II) and Fe (III) precursors. It can spread up to $20 \mathrm{~m}$ in groundwater with a reactivity duration of about 4 to 8 weeks, targeting soil and water pollutants [53]. The iron oxide nanoparticles and their modified forms such as $\alpha-\mathrm{Fe}_{2} \mathrm{O}_{3}, \mathrm{Fe}_{3} \mathrm{O}_{4} @$ GPTMS@P-Lys (polylysine incorporated $\mathrm{FeO}_{4}$ nanoparticles), $\mathrm{MnO}_{5} \mathrm{CuO}_{5} \mathrm{Fe}_{2} \mathrm{O}_{4}$ nanospinels and Amorphous $\mathrm{Fe}_{2} \mathrm{O}_{3}, \mathrm{CoO}$, NiO metal oxide nanoparticles have exhibited potential dye removal capacity for Orange II (OII), Methylene Blue (MB); Acid Red 18 (AR18), Brilliant Green (BG), and Methylene Blue (MB) dyes respectively.

The $\alpha-\mathrm{Fe}_{2} \mathrm{O}_{3}$ nanoparticles act on OII, which is a common type of azo dye. At room temperature, the electrostatic force of attraction among dye and adsorbent's surface helps in decolorization. Positively, the regeneration of iron oxide nano sorbent from dye-adsorbent complexes is possible by catalytic combustion with retained adsorption rate of the material. The methylene blue removal testing was done by amorphous $\mathrm{Fe}_{2} \mathrm{O}_{3}, \mathrm{CoO}, \mathrm{NiO}$ metal oxide nanoparticles synthesized through the green method under laser irradiation in a liquid medium [41]. Spherical iron oxide nanoparticles synthesized using leaves extracts of Teucrium polium having a size of 5.68 to $30.29 \mathrm{~nm}$ were catalyzed by $\mathrm{H}_{2} \mathrm{O}_{2}$ helps decolorize $73.6 \%$ of Methyl Orange (MO) dye inverted $6 \mathrm{~h}$ [54]. Moreover, the polyacrylic acid-coated iron oxide nanoparticles were also found to have dye removal efficacy. The removal of anionic dyes acid Red 57 (AR57) and Remazol Red (RR) in an aqueous solution was removed effectively by using porous magnetite $\mathrm{Fe}_{3} \mathrm{O}_{4}$ nanospheres [55].

\subsubsection{Zinc oxide nanoparticles.}

$\mathrm{ZnO}$ nanoparticles have been surface modified for UV light scavenging, as shown in earlier studies. The other nanostructures of $\mathrm{ZnO}$, such as nanoflower, have also shown their efficiency in degrading amyloids. It has also been used to design biosensors to detect insulin amyloids [56-58]. ZnO nanoparticles were used in photo remediation of toxic dyes [41]. The leaf extracts of Artocarpus heterophyllus aided $\mathrm{ZnO}$ nanoparticle synthesis was utilized for photocatalysis Rose Bengal (RB) dye along with UV light illumination, $\mathrm{pH}$ 9, room temperature-dependent Congo Red (CR) dye remediation in one hour with adsorbent's concentration of $0.24 \mathrm{~g} / \mathrm{L}$ each showing $80 \%$ and $90 \%$ degradation efficacy [59].

\subsubsection{Copper oxide nanoparticles.}

The copper oxide nanoparticles coupled with activated carbon at $333 \mathrm{~K}$ shows $(0.01$ $0.06 \mathrm{~g}$ ) adsorption of Acid Blue 129 (AB129) dye within 25-30 min at an acidic $\mathrm{pH}$ of 2 [41]. Photocatalytic activity of biologically synthesized copper $(\mathrm{Cu})$ nanoparticles with Citrus grandis plant degrades organic Methylene Blue (MB) dye [43]. Arsenic removal was attempted by using $\mathrm{CuO}$ nanoparticles along with the removal of microorganisms. Although, there are limitations to using $\mathrm{CuO}$ because the irreversible property of the combination of $\mathrm{CuO}$ leads to the dynamic reduction of surface area. This may reduce the arsenic remediation property from 
contaminated water [60]. In another study, copper oxide nanostructures of different shapes such as clusters, porous nanosheets, rods, and oval were synthesized by electromagnetic waveassisted synthesis. The synthesized nanostructures were characterized using photophysical tools like- TEM, XRD, and energy dispersive spectroscopy. The capacity of these synthesized nanostructures of copper oxide was monitored for the absorptive remediation of $\mathrm{Pb}$ (II) from contaminated water. The study showed that $\mathrm{CuO}$ could adsorb $\mathrm{Pb}$ (II) at an optimum $\mathrm{pH}$ of 6.5 , with a $4 \mathrm{~h}$ time of contact. The different nanostructures such as clusters, oval, small rod, leaves, and porous nanosheets had a maximum capacity of $\mathrm{Pb}(\mathrm{II})$ remediation at $116,125,120,117$, and $115 \mathrm{mg} / \mathrm{g}$, thereby effectively remove the $\mathrm{Pb}(\mathrm{II})$ from aqueous solutions [61].

\subsubsection{Titanium dioxide $\left(\mathrm{TiO}_{2}\right)$ nanoparticles based nanoadsorbents.}

Titanium dioxide nanoparticle was one of the well-known photocatalyst used in a variety of commercial areas. An organic PTCDI/P25- $\mathrm{TiO}_{2}$ nanoparticle decomposes Methyl Orange (MO) dye. Inorganic 3D- $\mathrm{MnWO}_{4}-\mathrm{TiO}_{2}$ nanoparticles and $\mathrm{TiO}_{2} / \mathrm{LDH}$ nanomaterial was found to have dye removal properties [62]. In a recent study, poly(lactic-co-glycolic) acid and chitosan were used to make electrospun nanofibrous mats and were coated with titanium dioxide $\left(\mathrm{TiO}_{2}\right)$ and reduced graphene oxide ( $\left.\mathrm{rGO}\right)$ for improved arsenic oxidation. The oxidative properties of UV-irradiated and non-irradiated nanofibers and only $\mathrm{TiO}_{2}$ nanoparticles were compared for arsenic oxidation. The results demonstrated 2.5 times enhanced arsenic oxidation which was treated with UV irradiated nanofibrous mats [63]. Figure 1 demonstrates the mechanism of organic dye removal using metal oxide nanoparticles.

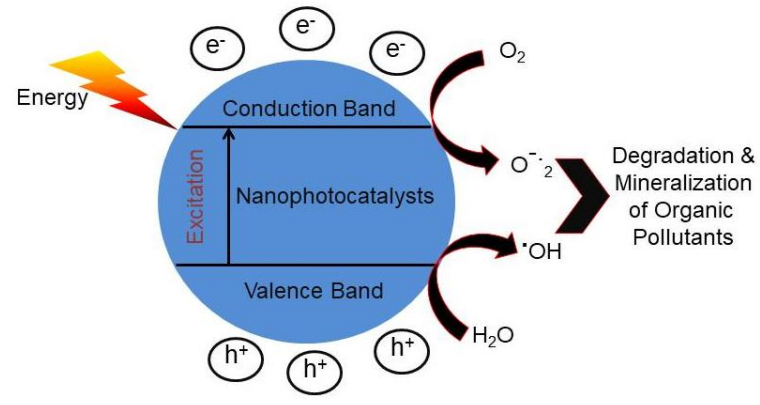

Figure 1. The mechanism of pollutant removal using metal oxide nanoparticles. When light falls on the metal oxide nanoparticles, which are semiconductors in nature, there is the excitation of electrons from the valance band to the conduction band, which produces superoxide radicals. These radicals degrade and mineralize the organic pollutants.

\section{Graphene Oxide (GO) Nanoparticles Based Nanoadsorbents}

Graphene oxide (GO) nanoparticles act as the best supportive component in photocatalyst for the zero-bandgap property. Magnetic Chitosan Graphene oxide (MCGO) organic nanomaterial was used to break down Methylene Blue (MB) dye. Ethylenediamine modified Chitosan nanoparticles (EMCN) were acting as a dye adsorbent. Organic Exfoliated graphene oxide (EGO) and reduced graphene oxide (RGO) possessed anionic and cationic dye adsorbent activity and were found to be effective [64].

\section{Carbon-Based Nanosorbents}

Different forms of carbon nano adsorbents are Activated carbon, Carbon nanotubes (Single-walled carbon nanotubes and multi-walled carbon nanotubes), graphene, fullerenes $\left(\mathrm{C}_{60}, \mathrm{C}_{540}\right)$, and carbon quantum dots [65]. 
12.1. Carbon quantum dots (CQDs).

Carbon quantum dots are a newly emerging nanomaterial having a size below 10nm. CQDs are synthesized by both bottom-up and top-down approaches using precursors from synthetic and green sources. Solvothermal treatment, microwave reactor, pyrolysis, and hydrothermal reactors were employed in the bottom-up strategy. CQDs and their conjugated composites were applied for the active elimination of dyes. The carbon networks in the core are arranged in crystalline and unstructured fashion with carbon $\mathrm{sp}^{3}$ bonded sheets like graphene, graphene oxide, graphite, and turbostratic carbon. Functional groups such as carboxyl, epoxy, and carbonyl groups at the CQDs surface increase oxygen level, which helps in flexible surface modification, redox reaction, and doping. It also has improved photobleaching resistance, photocatalytic activity, photoluminescence, anti-bacterial activity, thermal and chemical stability. The use of CQDs for the degradation of different dyes is given in Table 2.

Table 2. Degradation of various dyes using Carbon Quantum Dots (CQDs) and their types.

\begin{tabular}{|c|c|c|c|c|c|c|}
\hline Sl.no. & Type of CQD & Target dye & $\begin{array}{l}\text { Degradation } \\
\text { percentage/ } \\
\text { photocatalytic } \\
\text { activity }\end{array}$ & $\begin{array}{l}\text { Degradatio } \\
\text { n time } \\
\text { taken }\end{array}$ & $\begin{array}{l}\text { Type of } \\
\text { irradiation }\end{array}$ & Reference \\
\hline 1 & N-doped CQDs & $\begin{array}{ll}\text { Rose } & \text { Bengal } \\
\text { (RB) } & \end{array}$ & $93 \%$ & $30 \mathrm{~min}$ & Visible light & {$[66]$} \\
\hline 2 & $\begin{array}{l}\text { Hydrophobic CQDs } \\
\text { encapsulated inside } \\
\text { polyurethane foil }\end{array}$ & $\begin{array}{l}\text { Organic Rose } \\
\text { Bengal (RB) }\end{array}$ & $90 \%$ & $90 \mathrm{~min}$ & Blue light & [67] \\
\hline 3 & $\begin{array}{l}\text { Gamma rays } \\
\text { modified } \\
\text { CQDs/polyurethane } \\
\text { nanocomposites }\end{array}$ & $\begin{array}{ll}\text { Rose } & \text { Bengal } \\
\text { (RB) } & \end{array}$ & $97 \%$ & $180 \mathrm{~min}$ & $\begin{array}{ll}200 & \mathrm{kGy} \\
\text { gamma } & \text { rays } \\
\text { irradiation } & \end{array}$ & {$[68]$} \\
\hline 4 & $\begin{array}{l}\text { CQDs/TiO } \\
\text { composite } \\
\text { nanofibers }\end{array}$ & $\begin{array}{l}\text { Organic } \\
\text { methylene } \\
\text { blue (MB) }\end{array}$ & $100 \%$ & $95 \mathrm{~min}$ & Visible light & [69] \\
\hline 5 & $\begin{array}{l}\mathrm{N} \text { doped CQDs/TiO } \\
\text { hybrid composite }\end{array}$ & $\begin{array}{l}\text { Methylene } \\
\text { Blue (MB) }\end{array}$ & $86.9 \%$ & $420 \mathrm{~min}$ & Visible light & [70] \\
\hline 6 & $\begin{array}{l}\mathrm{CQDs} / \mathrm{TiO}_{2} \\
\text { nanocomposites }\end{array}$ & $\begin{array}{l}\text { Methylene } \\
\text { Blue (MB) }\end{array}$ & $91 \%$ & $60 \mathrm{~min}$ & UV light & [71] \\
\hline 7 & $\begin{array}{l}\text { NCQDs/ } \\
\mathrm{TiO}_{2} \\
\text { nanocomposites }\end{array}$ & $\begin{array}{l}\text { Rhodamine } \\
\text { B }(\mathrm{RhB})\end{array}$ & $>95 \%$ & $30 \mathrm{~min}$ & Visible light & [72] \\
\hline 8 & $\begin{array}{l}\text { 5\%-CQDs/meso- } \\
\mathrm{TiO}_{2}\end{array}$ & $\begin{array}{l}\text { Methylene } \\
\text { Blue (MB) } \\
\end{array}$ & $98 \%$ & - & Visile light & [73] \\
\hline 9 & $\begin{array}{l}\text { Novel } \\
\mathrm{CQD} / \text { hydrogenated } \\
\mathrm{TiO}_{2} \text { nanobelts }\end{array}$ & $\begin{array}{l}\text { Organic } \\
\text { Methyl } \\
\text { Orange (MO) } \\
\end{array}$ & $\begin{array}{l}\text { Enhanced } \\
\text { photocatalytic } \\
\text { activity }\end{array}$ & - & $\begin{array}{l}\text { UV/visible/ } \\
\text { NIR light }\end{array}$ & [74] \\
\hline 10 & $\begin{array}{l}\text { N-CQDs/ZnO } \\
\text { Composites }\end{array}$ & $\begin{array}{l}\text { organic dyes } \\
\text { (Malachite } \\
\text { Green (MG), } \\
\text { Methylene } \\
\text { Blue (MB), } \\
\text { and } \\
\text { Fluorescein } \\
\text { dye }\end{array}$ & $\begin{array}{l}\text { Better } \\
\text { photocatalytic } \\
\text { activity }\end{array}$ & $30-45 \mathrm{~min}$ & Daylight & [75] \\
\hline 11 & $\begin{array}{l}\text { CQDs/ZnO } \\
\text { nanocomposites } \\
\text { annealed at } 200^{\circ} \mathrm{C}\end{array}$ & $\begin{array}{l}\text { Rhodamine B } \\
(\mathrm{RhB})\end{array}$ & $94 \%$ & $105 \mathrm{~min}$ & Visible light & [76] \\
\hline 12 & $\begin{array}{l}\text { 3D novel } \\
\text { CQDs/ZnO } \\
\text { nanoflowers } \\
\text { composites }\end{array}$ & $\begin{array}{l}\text { Organic } \\
\text { Rhodamine B } \\
(\mathrm{Rh} \mathrm{B})\end{array}$ & $10-98 \%$ & - & Visible light & [77] \\
\hline 13 & $\begin{array}{l}\mathrm{ZnO} \text { foam/CQDs } \\
\text { nanocomposites }\end{array}$ & $\begin{array}{l}\text { Methylene } \\
\text { Blue (MB), } \\
\text { Methyl } \\
\text { Orange (MO) }\end{array}$ & $\begin{array}{l}\text { Good } \\
\text { photocatalytic } \\
\text { activity }\end{array}$ & - & - & [78] \\
\hline
\end{tabular}




\begin{tabular}{|c|c|c|c|c|c|c|}
\hline Sl.no. & Type of CQD & Target dye & $\begin{array}{l}\text { Degradation } \\
\text { percentage/ } \\
\text { photocatalytic } \\
\text { activity }\end{array}$ & $\begin{array}{l}\text { Degradatio } \\
\text { n time } \\
\text { taken }\end{array}$ & $\begin{array}{l}\text { Type of } \\
\text { irradiation }\end{array}$ & Reference \\
\hline & & $\begin{array}{l}\text { and } \\
\text { Rhodamine B } \\
(\mathrm{Rh} \mathrm{B}) \\
(\mathrm{MB}>\quad \mathrm{RhB} \\
>\mathrm{MO})\end{array}$ & & & & \\
\hline 14 & $\begin{array}{l}\mathrm{CQDs} / \mathrm{Ag} / \mathrm{AgPO}_{4} \\
\text { nanocomposites }\end{array}$ & $\begin{array}{l}\text { Methyl } \\
\text { Orange (MO) }\end{array}$ & $\begin{array}{l}\text { Greatest } \\
\text { photocatalytic } \\
\text { activity }\end{array}$ & $10 \mathrm{~min}$ & Visible light & [79] \\
\hline 15 & $\begin{array}{l}\mathrm{CQDs} / \mathrm{TiO}_{2} \\
\text { containing } \\
\text { waterborne } \\
\text { hyperbranched } \\
\text { polyester } \\
\text { nanocomposite } \\
\end{array}$ & $\begin{array}{l}\text { i)Methyl } \\
\text { Orange (MO), } \\
\text { ii) Methylene } \\
\text { Blue (MB) }\end{array}$ & Better effiency & $\begin{array}{l}\text { i) } 60 \mathrm{~min} \\
\text { ii) } 120 \mathrm{~min}\end{array}$ & Sun light & {$[80]$} \\
\hline 16 & $\mathrm{CQDs} / \mathrm{Bi}_{2} \mathrm{MoO}_{6}$ & $\begin{array}{l}\text { Rhodamine B } \\
\text { (RhB) }\end{array}$ & $97.1 \%$ & $50 \mathrm{~min}$ & Solar light & [81] \\
\hline 17 & $\begin{array}{l}\mathrm{CQDs} / \mathrm{Bi}_{2} \mathrm{WO}_{6} \\
\text { hybrid }\end{array}$ & $\begin{array}{l}\text { Methyl } \\
\text { Orange (MO) }\end{array}$ & $\begin{array}{l}\text { Good } \\
\text { photocatalytic } \\
\text { activity }\end{array}$ & & & [82] \\
\hline 18 & $\begin{array}{l}\text { Cerium oxide } \\
\text { heteroatom doped } \\
\text { CQDs/RGO } \\
\text { (HDCQD@RGO } \\
\text { nanohybrid catalyst }\end{array}$ & $\begin{array}{l}\text { i)Methyl } \\
\text { Orange (MO) } \\
\text { and } \\
\text { ii)Methylene } \\
\text { Blue (MB) }\end{array}$ & $\begin{array}{l}\text { i) } 95 \% \text { and } \\
\text { ii) } 81 \%\end{array}$ & $\begin{array}{l}\text { i) } 60 \mathrm{~min} \\
\text { and } \\
\text { ii) } 60 \mathrm{~min}\end{array}$ & Visible light & [83] \\
\hline 19 & $\begin{array}{l}1 \% \text { CQDs doped } \\
\text { CdS }(\mathrm{C} / \mathrm{CdS})\end{array}$ & $\begin{array}{l}\text { Rhodamine B } \\
\text { (RhB) }\end{array}$ & $90 \%$ & $60 \mathrm{~min}$ & Visible light & {$[84]$} \\
\hline
\end{tabular}

\subsection{Carbon nanotubes (CNTs).}

Carbon nanotubes are hollow cylindrical tubes with carbon atoms in a hexagonal fashion. The porous structure provides greater adsorption surface area. The hydrophobic characteristics, $\pi-\pi$ electronic interaction, play a major role in collaboration with other materials. Carbon nanotubes are of two types: Single-walled nanotubes (SWNTs) and Multiwalled carbon nanotubes (MWNTs). Single-walled carbon nanotubes exist in bundles as one nanotube attached with six nanotubes, whereas the multi-walled nanotubes have different forms as per synthesis methods. Carbon nanotubes with open ends have different adsorption locations ranging from higher adsorption inside and between single carbon nanotubes to lesser adsorption rates among outer regions of carbon nanotube bundles. Single-walled carbon nanotubes' adsorption ability was found to be greater than multi-walled carbon nanotubes. Under controlled $\mathrm{pH}$, the electrostatic attraction of carbon nanotubes increases adsorption among cationic dyes [65].

Multi-walled carbon nanotubes (MWNTs) functionalized with magnetic nanoparticles shows potential cationic dyes decolorization in methylene blue (MB), thionine (Th), crystal violet $(\mathrm{CV})$, and janus green $\mathrm{B}$ (JG-B). Chitosan beads incorporated carbon nanotubes (CNTs) acts as better dye removing agents. Methylene Blue (MB) has $41.63 \mathrm{mg} / \mathrm{g}$ adsorption by carbon nanotubes at 333K. Moreover, other dyes, including cationic Methylene Blue (MB), Reactive Blue 4 (RB4), and anionic orange II (OII), were also analyzed for decolorization with single and multi-walled carbon nanotubes [41]. $\mathrm{CNTs} / \mathrm{Fe}-\mathrm{Ni} / \mathrm{TiO}_{2}$ nanomaterial helps in the degradation of Methylene Blue (MB) dye, and CS-MWCNT was used for Congo Red (CR) dye remediation [43].

\subsection{Activated carbon.}


Activated carbon is more advantageous than metallic nanomaterials due to its structural configuration, flexible hybridization with distinct electronic, physicochemical properties with greater surface area, modifiable pore size, successful adsorption to acid, disperse, cationic and reactive dyes. Furthermore, the efficiency can be improved by increasing the dosage of carbon. It has fewer limitations of higher cost, 10-15\% sorbent loss during recycling. Advantage of harmful carcinogenic dyes removal by Magnesium oxide nanoparticles encapsulated Activated carbon [41].

\section{Nanoscale Zero Valent Iron (nZVI)}

For more than twenty years, nanoscale zero valent iron was widely used in in-situ treatment for removing most pollutants in groundwater, soil, and wastewater [42]. The reduction potential of $\mathrm{nZVI}$ (Fe/Fe (II)) was found to be $20.447 \mathrm{~V}$ making it a powerful reducing material. Dye degradation follows a sequence of mechanisms: adsorption of dye by nZVI adsorbent; surface oxidation followed by electron transfer to dye causing reduction reaction (Redox reaction); formation of complex and finally the less toxic products were coprecipitated [85]. Redox reaction takes place in nZVI using the iron inner core, reducing pollutants, and the outer surface aids in the functionalization and production of oxidizing agents like hydrogen ions, hydrogen, oxides, hydroxides, iron hydroxides, and $\mathrm{Fe}(\mathrm{II})$. A pH of the medium determines the degradation rate by accelerating at $\mathrm{pH} 4$ because of corrosion of iron and dissolution on the surface and slowing at greater $\mathrm{pH}$ by ferrous hydroxide precipitation. It has significant advantages such as low cost, adaptability, simplified production, potential reduction, greater magnetism, less toxic than other materials, and biocompatibility [42].

nZVI was synthesized from aqueous iron salts by top-down and bottom-up approaches through reduction (sodium borohydride as reductant) and precipitation methods. The nZVI subjected to dye effluents containing added ferrous ion (40-80 ppm) performs a wide range of rapid organic degradation using Fenton's Advanced Oxidation Process (AOP). Difficulties in the biological degradation of azo dyes and their toxic products can be resolved by nZVI. Methyl Orange (MO) dye was completely decolorized in 10 min along with by-products of N-methylp-phenylenediamine, N,N-dimethyl-p-phenylene diamine, and sulfanilic acid confirmed using Gas Chromatography and Mass Spectroscopy (GCMS). Reactive Red 198 (RR198) and Reactive Black 5 (RB5) dyes were decolorized by $\mathrm{Pd}$, and $\mathrm{TiO}_{2}$ added nZVI anchored upon silica, sand, and biological sludge using photocatalytic reduction under a low $\mathrm{pH}$ system. nZVI embedded on cation exchange resin removes acid Blue 113 (AB113) with higher efficiency in 30 min using pseudo-first-order kinetics. For AB24 dye removal, nZVI subjected to $\mathrm{pH}$ less than 6 facilitate reduction, whereas in contrast improves adsorption at $\mathrm{pH}$ greater than 6 . The bentonite-supported nZVI with FeO clay material was tested on Orange (II) dye that resulted in enhanced reactivity, and a greater reduction of dye from $96.5 \mathrm{mg} / \mathrm{l}$ (initial concentration) to $3 \mathrm{mg} / \mathrm{l}$ was observed [85]. A novel composite of nZVI encapsulated with Hangjin 2\# natural clay (HJ clay) acts as a carrier in an aqueous medium and reduces Methyl Orange dye by providing stability, reducing agglomeration, and increasing mobility. The cation exchange resin immobilized nZVI exhibits faster azo dye removal, which is water-soluble. It can also be employed for disinfection for its bactericidal effects on Escherichia coli and kills viruses such as X174 and MS-2. Moreover, motility, distribution, and stability can be achieved by metal doping ( $\mathrm{Pt}, \mathrm{Cu}, \mathrm{Ag}, \mathrm{Pd}$, and Ni nanoparticles) in nZVI, which can increase the catalytic synergy with iron. 
During remediation of dyes in industrial water effluents, the addition of nanoscale Zero Valent Iron (nZVI) in FePd bimetallic nanoparticles supported on silica or activated carbon can exhibit maximized catalytic reduction of pollutants [42]. Nanoscale Zero Valent Iron (nZVIs) was proven for producing good water quality in distillery wastewater decontamination [86]. Usage has been increasing due to its advancement and promising results without a proper idea about the material's impact [87]. Limitations include aggregation and toxicity assessed in aquatic life can be reduced by surface modifications, polymeric coatings, dose-dependent Insitu, Ex-situ application, and growth of safer materials [85]. Despite many uncertainties in selecting the perfect nanomaterial for water remediation, the use of magnetic sorbents and Nanoscale Zero Valent Iron (nZVI) conjugated persulphate nanomaterials could overcome the limitations of conventional chemicals [88].

\section{Nanofiltration (NF) Membranes}

Nanofabrication technology designed a membrane for water filtration and contaminants resistance called Nanomembranes or Nanofiltration membranes [41, 42]. Depending on the structure, it can be classified into two groups: thin-film nanocomposite membranes and Mixed matrix membranes [42]. The membranes were mostly synthesized using nanoparticles to increase the permeability potential, catalytic reduction, and inhibition to fouling membranes. It was advantageous in many ways like easy production, low manufacturing cost, less energy requirement, low space accommodation, successful remediation, and greater rejection rates to organic low molecular weight molecules and multivalent ions [41, 42]. This technology was extensively implemented for its advantages in textile dye removal and replaced the conventional Reverse Osmosis (RO system) for contaminants in wastewater effluents. Though the NF membranes have greater flux rates, fouling of membranes can lead to a decrease in flux which can be combated by proper cleaning and altering feed pre-treatment [41].

Most often, interfacial polymerization was applied for designing thin-film composite over ultrafiltration substrates. During fabrication, nanoparticles like Titanium dioxide $\left(\mathrm{TiO}_{2}\right)$, Silver (Ag), especially Carbon Nano Tubes (CNTs) are preferred for their antimicrobial activity, and Zeolites are repeatedly used for their permeability enhancement in NF membranes [42]. From the evident researches, NF membranes exhibit strong rejection against dye molecules during the filtration process. The dye rejection percentage for NF45; DK1073, and MPS 31 were 95-99\% and 90-97\%, respectively. Because of the high molecular weight cutoff, the second layer of MPF 36 NF membrane shows greater efficiency with chloride and reactive dye. The dye rejection rate does not change while increasing the dye concentration from 92 to $1583 \mathrm{ppm}$ at 5 bar pressure. This favors the hypothesis of independence between dye concentration and rejection, whereas the cross-flow velocity is responsible for effluent decolorization potential [41].

\section{Enzyme Incorporated Nanotechnology}

Enzyme incorporated nanotechnology is the immobilization of enzymes in nanomaterial, providing a greater chance for dye remediation applications. Comparative studies between enzymes immobilized nanomaterial versus the free enzyme catalytic activity towards dyes were observed. Positively, there was enhanced kinetics in reactivity, temperature stability, wide $\mathrm{pH}$ activity, and recycling among enzyme incorporated nanomaterial biocatalysts than free forms. 
Laccase immobilized in a self-assembled copper phosphate, Graphene oxide, carbon nanotubes (CuP-GO-CNT) hybrid nanocomposite subjected to Neutral Red and Crystal Violet shows $100 \%$ dye decolorization, while the free laccase could reach $20 \%$ only. In addition, the enzyme composite could retain above $80 \%$ of catalytic action after 6 days of storage at room temperature, whereas the only enzyme retained $30 \%$ of its primary activity. Aminofunctionalized silica-coated $\mathrm{TiO}_{2}$ nanoparticles with Ginger peroxidase immobilization demonstrated greater dye removal activity of nearly $80 \%$ in acidic as well as basic $\mathrm{pH}$ at a temperature of $60^{\circ} \mathrm{C}$ for $100 \mathrm{~min}$. At the same time, the free enzyme form was only $10 \%$ reactive confirms the advantage of nanomaterial support. When laccase was immobilized in $\mathrm{Fe}_{3} \mathrm{O}_{4} / \mathrm{SiO}_{2}$ nanoparticles exhibited initial degradation activity of $79 \%$ in Procion Red MX-5B dye. Also when reused, withstands same percentage efficacy continued throughout 10 cycles. Laccase immobilized Poly ( $p$-Phenylenediamine) $/ \mathrm{Fe}_{3} \mathrm{O}_{4}$ nanocomposite showing only $43 \%$ dye reduction in Reactive Blue 19 without sustained reusability.

A temperature-dependent study of laccase immobilized chitosan nanoparticles encapsulated glass beads versus a free form of laccase subjected to congo red (CR) dye at 90 ${ }^{\circ} \mathrm{C}$ showing sustained dye degradation and complete loss of free enzyme activity, respectively. Limitations of enzyme incorporated technology include a limited number of studies, diffusional immobility in a real-time application, lack of proper conformational structural changes, and difficulty producing larger products. And these could be resolved in future approaches to biocatalysts for wastewater treatment [44].

\section{Microbial Nanotechnology}

A novel bio-nano-metal construct of transition metals precipitated over the surface of bacteria, forming nanoparticulate catalyst in a single step. Pd nanoparticles were produced by $\mathrm{Pd}(\mathrm{II})$ ions reduction using genus Clostridia, and bio-Pd nanoparticles conjugate was generated by Clostridia pasteurianum $\mathrm{BC} 1$ cultures in cell walls of bacteria. Bio-Pd loaded bacterial cells were tested on organic Methyl Orange (MO) and Evans Blue dyes with successful dye reduction by reductive hydrogenation of azo dyes at the azo linkage and with the help of molecular hydrogen produced by bacterial cells. Among the present nanomaterials, bio-Pd acts as a simple and potential biocatalyst than other costly complex methods [45].

\section{Nanoclays}

Many reviews have discussed wastewater remediation using microorganisms and chemical, ecological and biological processes $[89,90]$. Nanoclays are used for their structural and functional specialty. These minerals have spaces among layers that can help to adsorb negatively charged ions, positively charged ions, and $\mathrm{H}_{2} \mathrm{O}$ molecules. Temporary porosity was considered a limitation. This can be resolved by laboring molecular pillars between the layers. It results in swelling and increased spaces for adsorbate accommodation. Congo red dye was tested with chitosan biopolymer / montmorillonite (CTS/MMT) nanocomposite showed a $54.52 \mathrm{mg} / \mathrm{g}$ adsorption rate. The dye removal capacity increases with a proportional increase in CTS in CTS/MMT nanocomposite [91]. The two compositions of nanoclays were used, namely- MgAl-LDH (2:1) and MgAl-LDH (3:1) for the remediation of anionic dye congo red with high efficiency [92]. Methylene blue and safranin were removed using Natural Safiot Clay (NSC) [93], and many natural products are also being studied for wastewater remediation. Plant biomass was used to remove anthocyanin dyes and azo dyes by using agricultural biomass- 
derived adsorbents, such as peel-based, leaf-based, stem-based, and seed-based adsorbents [94]. Figure 2 shows the application of plant-based cellulose nanocrystals and cellulose nanofibrils for the remediation of wastewater.

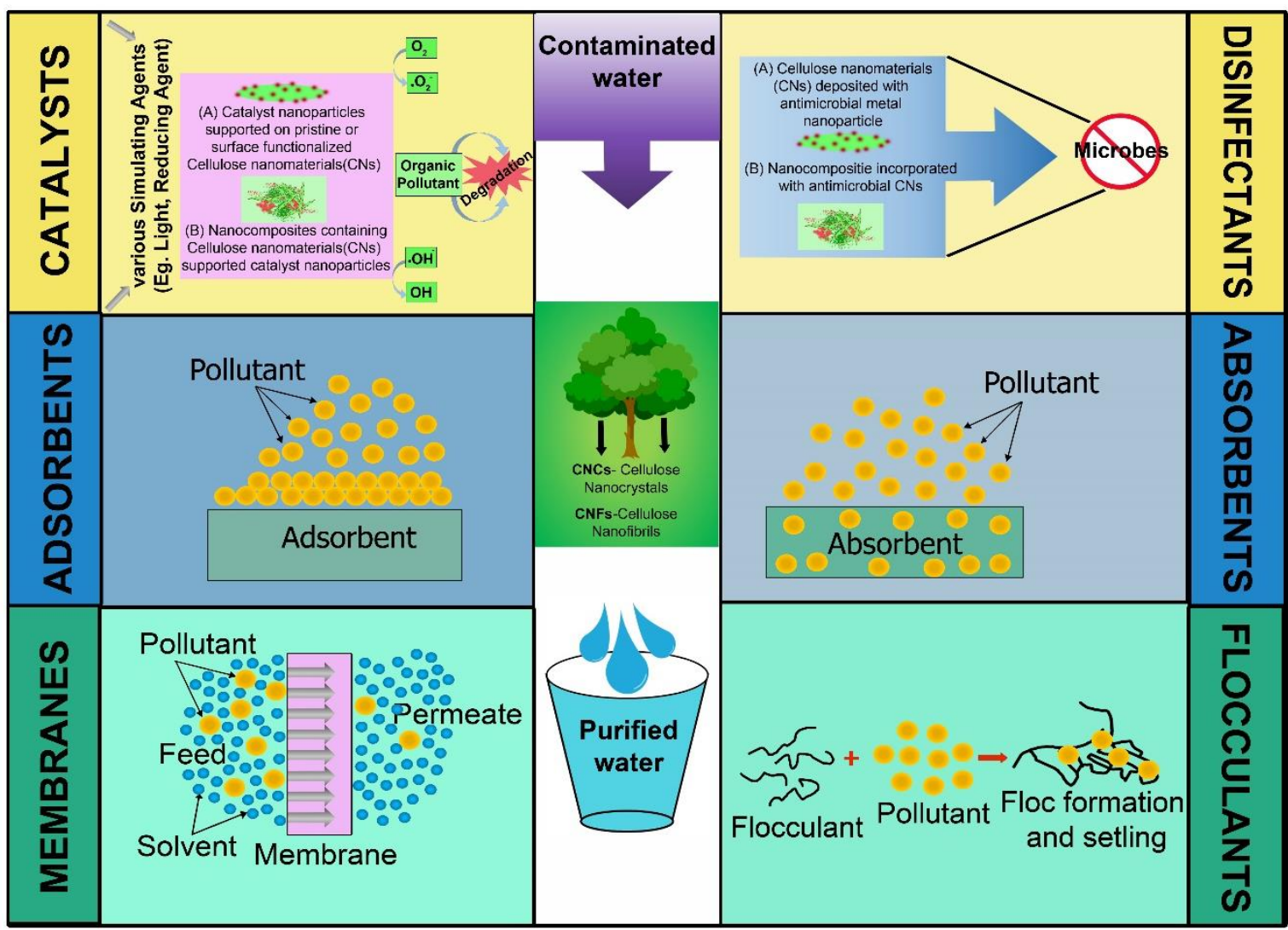

Figure 2. The different ways of wastewater remediation using plant-based cellulose nanocrystals and cellulose nanofibrils.

\section{Conclusion}

The present review has elaborately discussed the different types of remediation for wastewater. We have explained the types of dyes and the nanostructures, and the nanocomposites used for the remediation of the textile dyes. Pigment manufacturing, food industries, cosmetic industries, textile industries, printing, leather industries, etc., are the industries that use dyes. In the future, it will be possible to apply advanced nanotechnology for a sustainable environment by treating wastewater in a greener approach.

\section{Funding}

Dr. Agnishwar Girigoswami received a grant from the Council of Scientific and Industrial Research (CSIR), INDIA, Scheme No. 01(2868)/17/EMR-II.

\section{Acknowledgments}

The authors are grateful to Chettinad Academy of Research and Education, Kelambakkam, Tamilnadu, India, for providing the infrastructural support.

\section{Conflicts of Interest}

The authors declare no conflict of interest. 


\section{References}

1. Upadhyay, R.S. Microbial bioremediation of textile effluents. Prog. Indus. Microbiol. 2002, 36I, 331-348, https://doi.org/10.1016/S0079-6352(02)80018-2.

2. Ahmad, R.; Mondal, P.K. Application of Acid Treated Almond Peel for Removal and Recovery of Brilliant Green from Industrial Wastewater by Column Operation. Sep. Sci. Tech. 2009, 44, 1638-1655, https://doi.org/10.1080/01496390902775836.

3. Amini, M.; Younesi, H.; Bahramifar, N.; Akbar, A.; Lorestani, Z.; Ghorbani, F.; Daneshi, A.; Sharifzadeh, M. Application of response surface methodology for optimization of lead biosorptioninan aqueous solution by Aspergillus niger. J. Hazard. Mater. 2008, 154, 694-702, https://doi.org/10.1016/j.jhazmat.2007.10.114.

4. O’Neill, C.; Hawkes, F.R.; Hawkes, D.L.; Lourenco, N.D.; Pinherio, H.M.; Delee, W. Color in textile effluents sources, measurements, discharge consents and simulation. A review. J. Chem. Technol. Biotechnol. 1999, 74, 1009-1018, https://doi.org/10.1002/(SICI)1097-4660(199911)74:11<1009::AIDJCTB153>3.0.CO;2-N.

5. Ahmed, K.; Shahin, A.; Ragheb, A.; El-Hennawi, H. A Facile Synthesis with One Step of Disperse Azo Dyes to be Applied as Nano-Inks in Textile Printing. Biointerface Res. Appl. Chem. 2021, 11, 11713-11723, https://doi.org/10.33263/BRIAC114.1171311723.

6. Nelson, C.R.; Hites, R.A. Aromatic amines in and near the Buffalo River. Environ. Sci. Technol. 1980, 14, 1471-1149, https://doi.org/10.1021/es60169a020.

7. Mittal, A.; Mittal, J.; Malviya, A.; Kaur, D.; Gupta, V.K. Adsorption of hazardous crystal violet from waste water by waste materials. J. Colloid Inter. Sci. 2010, 343, 463-473, https://doi.org/10.1016/j.jcis.2009.11.060.

8. Senthilkumaar, S.; Kalaamani, P.; Subburaam, C.V. Liquid phase adsorption of crystal violet onto activated carbons derived from male flowers of coconut tree. J. Hazard. Mater. 2006, 136, 800-808, https://doi.org/10.1016/j.jhazmat.2006.01.045.

9. de la Cueva, S.C.; Rodriguez, C.H.; Cruz, N.O.S.; Contreras, J.A.R.; Miranda, J.L. Changes in Bacterial populations During Bioremediation of Soil Contaminated with petroleum Hydrocarbons. Water Air Soil Pollut. 2016, 227, https://doi.org/10.1007/s11270-016-2789-z.

10. Vidali, M. Bioremediation:An overview. J Appl. Chem. 2001, 73, 1163-1172, https://doi.org/10.1351/pac200173071163.

11. Gita, S.; Hussain, A.; Choudhury, T.G. Impact of Textile Dyes Waste on Aquatic Environments and its Treatment. Environ. Ecol.2017, 35, 2349-2353.

12. Brown, M.; Malpass, G.R.P.; de Jesus Motheo, A. Evaluation of electrochemical and photoelectrochemical treatments in the degradation of textile dyes (Avaliação dos tratamentos eletroquímico e fotoeletroquímico na degradação de corantes têxteis). Química Nova 2006, 29, 983-989, https://doi.org/10.1590/S010040422006000500018.

13. Al-Degs, Y.; Khraished, M.A.M.; Allen, S.J.; Ahmad, M.N. Effect of carbon surface chemistry on the removal of reactive dyes from textile effluent. Water Res. 2000, 34, 927-935, https://doi.org/10.1016/S00431354(99)00200-6.

14. Viswanathan, B. Photocatalytic Degradation of Dyes: An Overview. Current Catalysis 2018, 7, 99-121, https://doi.org/10.2174/2211544707666171219161846.

15. Raliya, R.; Avery, C.; Chakrabarti, S.; Biswas, P. Photocatalytic degradation of methyl orange dye by pristine titanium dioxide, zinc oxide, and graphene oxide nanostructures and their composites under visible light irradiation. Appl. Nanoscience 2017, 7, 253-259, https://doi.org/10.1007/s13204-017-0565-z.

16. Girigoswami, A.; Mitra Ghosh, M.; Pallavi, P.; Seenuvasan, R.; Girigoswami, K. Nanotechnology in Detection of Food Toxins - Focus on the Dairy Products. Biointerface Res. Appl. Chem. 2021, 11, 1415514172, https://doi.org/10.33263/BRIAC116.1415514172.

17. Girigoswami, K, Girigoswami, A. A Review on Role of Nanosensors in Detecting Cellular miRNA Expression in Colorectal Cancer. Endocr. Metab. Immune Disord Drug Targets 2021, 21, 12-26, https://doi.org/10.2174/1871530320666200515115723.

18. Metkar, S.K.; Girigoswami, K. Diagnostic Biosensors in Medicine- a Review, Biocatal. Agric. Biotech. 2019 , 17, 271-283, https://doi.org/10.1016/j.bcab.2018.11.029.

19. De, S.; Gopikrishna, A.; Keerthana, V.; Girigoswami, A.; Girigoswami, K. An Overview of Nano formulated Nutraceuticals and its therapeutic approaches. Current Nutrition Food Sci. 2021, 17, 392-407, https://doi.org/10.2174/1573401316999200901120458.

20. Ghosh, S.; Girigoswami, K.; Girigoswami, A. Membrane-encapsulated camouflaged nanomedicines in drug delivery. Nanomedicine (Lond.) 2019, 14, 2067-2082, https://doi.org/10.2217/nnm-2019-0155.

21. Sharmiladevi, P.; Breghatha, M.; Dhanavardhini, K.; Priya, R.; Girigoswami, K.; Girigoswami, A. Efficient Wormlike Micelles for the Controlled Delivery of Anticancer Drugs. Nanoscience Nanotechnology-Asia 2021, 11, 350-356, https://doi.org/10.2174/2210681210999200728115601.

22. Haribabu, V.; Sharmiladevi, P.; Akhtar, N.; Farook, A.S.; Girigoswami, K.; Girigoswami, A. Label Free Ultrasmall Fluoromagnetic Ferrite-clusters for Targeted Cancer Imaging and Drug Delivery. Current Drug Delivery 2019, 16, 233-241, https://doi.org/10.2174/1567201816666181119112410. 
23. Sharmiladevi, P.; Haribabu, V.; Girigoswami, K.; Abubacker, S.F.; Girigoswami, A. Effect of Mesoporous Nano Water Reservoir on MR Relaxivity. Scientific Reports 2017, 7, https://doi.org/10.1038/s41598-01711710-2.

24. Sharmiladevi, P.; Akhtar, N.; Haribabu, V.; Girigoswami, K.; Chattopadhyay, S.; Girigoswami, A. Excitation Wavelength Independent Carbon Decorated Ferrite Nanodots for Multimodal Diagnosis and Stimuli Responsive Therapy. ACS Appl. Biomater. 2019, 2, 1634-1642, https://doi.org/10.1021/acsabm.9b00039.

25. Haribabu, V.; Girigoswami, K.; Girigoswami, A. Magneto-silver Core-shell Nanohybrids for Theragnosis. Nano-Structures Nano-Objects 2021, 25, https://doi.org/10.1016/j.nanoso.2020.100636.

26. Girigoswami, A.; Yassine, W.; Sharmiladevi, P.; Haribabu, V.; Girigoswami, K. Camouflaged Nanosilver with Excitation Wavelength Dependent High Quantum Yield for Targeted Theranostic. Scientific Reports 2018, 8, https://doi.org/10.1038/s41598-018-34843-4 .

27. Sharmiladevi, P.; Girigoswami, K.; Haribabu, V.; Girigoswami, A. Nano-enabled Theranostics for Cancer. Materials Advances 2021, 2, 2876-2891, https://doi.org/10.1039/d1ma00069a.

28. Haribabu, V.; Girigoswami, K.; Sharmiladevi, P.; Girigoswami, A. Water-Nanomaterials Interaction to Escalate Twin-mode Magnetic Resonance Imaging. ACS Biomaterials Science Eng. 2020, 6, 4377-89, https://doi.org/10.1021/acsbiomaterials.0c00409.

29. Vimaladevi, M.; Divya, K.C.; Girigoswami, A. Liposomal Nanoformulations of Rhodamine for Targeted Photodynamic Inactivation of Multidrug Resistant Gram Negative Bacteria in Sewage Treatment Plant. $J$. Photochem. Photobiol B 2016, 162, 146-152, https://doi.org/10.1016/j.jphotobiol.2016.06.034.

30. Marković, Z.; Marković, B.T. Treating of Aquatic Pollution by Carbon Quantum Dots. In: Nanostructured Materials for Treating Aquatic Pollution. Springer: 2019; pp. 121-145, https://doi.org/10.1007/978-3-03033745-2_5.

31. Saikia, J.; Gogoi, A.; Baruah, S. Nanotechnology for water remediation. In: Environmental Nanotechnology. Springer: 2019; pp. 195-211, https://doi.org/10.1007/978-3-319-98708-8_7.

32. Khan, S.H. Green nanotechnology for the environment and sustainable development. In: Green materials for wastewater treatment. Springer: 2020; pp. 13-46, https://doi.org/10.1007/978-3-030-17724-9_2.

33. Hayati, F.; Isari, A.A.; Fattahi, M.; Anvaripour, B.; Jorfi, S. Photocatalytic decontamination of phenol and petrochemical wastewater through $\mathrm{ZnO} / \mathrm{TiO}_{2}$ decorated on reduced graphene oxide nanocomposite: influential operating factors, mechanism, and electrical energy consumption. $R S C A d v$. 2018, 8, https://doi.org/10.1039/C8RA07936F.

34. Giovannetti, R.; Rommozzi, E.; Zannotti, M.; D’Amato, C.A. Recent Advances in Graphene Based TiO Nanocomposites $\left(\mathrm{GTiO}_{2} \mathrm{Ns}\right)$ for Photocatalytic Degradation of Synthetic Dyes. Catalysts 2017, 7, https://doi.org/10.3390/catal7100305.

35. Tayel, A.; Ramadan, A.R.; El Seoud, O.A. Titanium Dioxide/Graphene and Titanium Dioxide/Graphene Oxide Nanocomposites: Synthesis, Characterization and Photocatalytic Applications for Water Decontamination. Catalysts 2018, 8, https://doi.org/10.3390/catal8110491.

36. Somasekhar, R.; Nookaraju, M. Nanotitania composite assembled with Graphene oxide for Photocatalytic degradation of Eosin Yellow under Visible light. Nanochem. Res. 2018, 3, 160-169, https://doi.org/10.22036/NCR.2018.02.005.

37. Raliya, R.; Avery, C.; Chakrabarti, S.; Biswas, P. Photocatalytic degradation of methyl orange dye by pristine titanium dioxide, zinc oxide, and graphene oxide nanostructures and their composites under visible light irradiation. Appl Nanosci 2017, 7, 253-259, https://doi.org/10.1007/s13204-017-0565-z.

38. Rosu, M.-C.; Coros, M.; Pogacean, F.; Magerusan, L.; Socaci, C.; Turza, A.; Pruneanu, S. Azo dyes degradation using $\mathrm{TiO}_{2}-\mathrm{Pt} /$ graphene oxide and $\mathrm{TiO}_{2}-\mathrm{Pt} /$ reduced graphene oxide photocatalysts under $\mathrm{UV}$ and natural sunlight irradiation. Solid State Sciences 2017, $70, \quad$ 13-20, https://doi.org/10.1016/j.solidstatesciences.2017.05.013.

39. Vallejo, W.; Rueda, A.; D1'az-Uribe, C.; Grande, C.; Quintana, P. Photocatalytic activity of graphene oxide$\mathrm{TiO}_{2}$ thin films sensitized by natural dyes extracted from Bactris guineensis. R. Soc. Open Sci. 2019, 6, http://dx.doi.org/10.1098/rsos.181824.

40. Tan, L.-L.; Ong, W.-J.; Chai, S.-P.; Mohamed, A. Reduced graphene oxide-TiO ${ }_{2}$ nanocomposite as a promising visible-light-active photocatalyst for the conversion of carbon dioxide. Nanoscale Research Lett. 2013, 8, https://doi.org/10.1186/1556-276X-8-465.

41. Yadav, M.; Khan, S. Nanotechnology: A New Scientific Outlook for Bioremediation of Dye Effluents. Approaches in Bioremediation 2018, 355-368, https://doi.org/10.1007/978-3-030-02369-0_16.

42. Pathakoti, K.; Manubolu, M.; Hwang, H.-M. Nanotechnology applications for environmental industry. In: Handbook of nanomaterials for industrial applications. Elsevier: 2018; pp. 894-907, https://doi.org/10.1016/B978-0-12-813351-4.00050-X.

43. Das, S.; Chakraborty, J.; Chatterjee, S.; Kumar, H. Prospects of biosynthesized nanomaterials for the remediation of organic and inorganic environmental contaminants. Environ. Sci.: Nano 2018, 5, 2784-2808, https://doi.org/10.1039/C8EN00799C.

44. Wong, J.K.H.; Tan, H.K.; Lau, S.Y.; Yap, P-S.; Danquah, M.K. Potential and challenges of enzyme incorporated nanotechnology in dye wastewater treatment: A review. J. Environ. Chem. Eng. 2019, 7, https://doi.org/10.1016/j.jece.2019.103261. 
45. Johnson, A.; Merilis, G.; Hastings, J.; Palmer, M.E.; Fitts, J.; Chidambaram, D. Nanotechnology and Microbial Electrochemistry for Environmental Remediation. ECS Transactions 2011, 33, 103-112, https://doi.org/10.1149/1.3583520.

46. Sabae, S.Z.; Eldourghamy, A.S.; Aly, S.A.; Rizk, N.M.H.; Sobhy, A. Immobilization of lignin peroxidase from Alcaligenes aquatilis and its application in dye decolorization. Lett. Appl. NanoBiosci. 2020, 9, 10581063, https://doi.org/10.33263/LIANBS92.10581063.

47. Das, A.; Kamle, M.; Bharti, A.; Kumar, P. Nanotechnology and it's applications in environmental remediation: an overview. Vegetos 2019, 32, 227-237, https://doi.org/10.1007/s42535-019-00040-5.

48. Saha, J.; Arjuara, B.; Mukherjee, A.; Kumar, S. A novel green synthesis of silver nanoparticles and their catalytic action in reduction of Methylene Blue dye. Sustainable Environment Research 2017, 27, 245-250, https://doi.org/10.1016/j.serj.2017.04.003.

49. Adoni, M.; Yadam, M.; Gaddam, S.A.; Rayalacheruvu, U.; Kotakadi, V.S. Antimicrobial, Antioxidant, and Dye Degradation Properties of Biosynthesized Silver Nanoparticles From Artemisia Annua L. Lett. Appl. NanoBiosci. 2021, 10, 1981-1992, https://doi.org/10.33263/LIANBS101.19811992.

50. Singh, J.; Kaur, N.; Kaur, P.; Kaur, S.; Kaur, J.; Kukkar, P.; Kumar, V.; Kukkar, D.; Rawat, M. Piper betle leaves mediated synthesis of biogenic $\mathrm{SnO}_{2}$ nanoparticles for photocatalytic degradation of reactive yellow 186 dye under direct sunlight. Environ. Nanotechnol. Monit. Manag. 2018, 10, 331-338, https://doi.org/10.1016/j.enmm.2018.07.001.

51. Bhattacharjee, A.; Ahmaruzzaman M. Photocatalytic-degradation and reduction of organic compounds using $\mathrm{SnO} 2$ Quantum Dots (via green route) under direct sunlight. $R S C A d v$. 2015, 5, 66122-66133, https://doi.org/10.1039/C5RA07578E.

52. Tammina, S.K.; Mandal, B.K.; Kadiyala, N.K. Photocatalytic degradation of methylene blue dye by nonconventional synthesized SnO2 nanoparticles. Environ. Nanotechnol. Monit. Manag. 2018, 10, 339-350, https://doi.org/10.1016/j.enmm.2018.07.006.

53. Zhang, W. Nanoscale iron particles for environmental remediation: An overview. J. Nanopart. Res. 2003, 5, 323-332, https://doi.org/10.1023/A:1025520116015.

54. Kouhbanani, M.A.; Beheshtkhoo, J.N.; Taghizadeh, S.; Amani, A.M.; Alimardani, V. One-step green synthesis and characterization of iron oxide nanoparticles using aqueous leaf extract of Teucrium polium and their catalytic application in dye degradation. Adv. Nat. Sci. Nanosci. Nanotechnol. 2019, 10.

55. El-Desouky, M.G.; Hassan, N.; Shahat, A.; El-Didamony, A.; El-Bindary, A.A. Synthesis and Characterization of Porous Magnetite Nanosphere Iron Oxide as a Novel Adsorbent of Anionic Dyes Removal from Aqueous Solution. Biointerface Res. Appl. Chem. 2021, 11, 13377-13401, https://doi.org/10.33263/BRIAC115.1337713401.

56. Girigoswami, K.; Meenakshi, V.; Murugesan, R.; Girigoswami, A. Studies on Polymer-Coated Zinc Oxide Nanoparticles: UV-blocking Efficacy and in vivo Toxicity. Mater. Sci. Eng. C 2015, 56, 501-510, https://doi.org/10.1016/j.msec.2015.07.017.

57. Girigoswami, A.; Ramalakshmi, M.; Akhtar, N.; Metkar, S.K.; Girigoswami, K. ZnO Nanoflower petals mediated amyloid degradation - an in vitro electrokinetic potential approach. Mater. Sci. Eng. C 2019, 101, 169-178, https://doi.org/10.1016/j.msec.2019.03.086.

58. Akhtar, N.; Metkar, S.K.; Girigoswami, A.; Girigoswami, K. ZnO nanoflower based sensitive nano-biosensor for amyloid detection. Mater. Sci. Eng. C 2017, 78, 960-968, https://doi.org/10.1016/j.msec.2017.04.118.

59. Vidya, C.; Chandra Prabha, M.N.; Antony Raj, M.A.L. Green mediated synthesis of zinc oxide nanoparticles for the photocatalytic degradation of Rose Bengal dye. Environmental Nanotech Monitor Management 2016, 6, 134-138, https://doi.org/10.1016/j.enmm.2016.09.004.

60. McDonald, K.J., Reddy, K.J., Singh, N.; Singh, R.P.; Mukherjee, S. Removal of arsenic from groundwater in West Bengal, India using $\mathrm{CuO}$ nanoparticle adsorbent. Environ Earth Sci 2015, 73, 3593-3601, https://doi.org/10.1007/s12665-014-3645-3.

61. Farghali, A.A.; Bahgat, M.; Enaiet Allah, A.; Khedr, M.H. Adsorption of $\mathrm{Pb}(\mathrm{II})$ ions from aqueous solutions using copper oxide nanostructures. Beni-Suef University Journal of Basic and Applied Sciences 2013, 2, 6171, https://doi.org/10.1016/j.bjbas.2013.01.001.

62. Gopinath, K.P.; Madhav, N.V.; Krishnan, A.; Malolan, R.; Rangarajan, G. Present applications of titanium dioxide for the photocatalytic removal of pollutants from water: A review. J. Environ. Management 2020, 270, https://doi.org/10.1016/j.jenvman.2020.110906.

63. Fausey, C.L.; Zucker, I.; Shaulsky, E.; Zimmerman, J.B.; Elimelech, M. Removal of arsenic with reduced graphene oxide- $\mathrm{TiO}_{2}$-enabled nanofibrous mats. Chemical Engineering J. 2018, 375, https://doi.org/10.1016/j.cej.2019.122040.

64. Fan, L.; Luo, C.; Sun, M.; Li, X.; Lu, F.; Qiu, H. Preparation of novel magnetic chitosan/graphene oxide composite as effective adsorbents toward methylene blue. Bioresource Technology 2012, 114, 703-706, https://doi.org/10.1016/j.biortech.2012.02.067.

65. Guerra, F.D.; Attia, M.F.; Whitehead, D.C.; Alexis, F. Nanotechnology for Environmental Remediation: Materials and Applications. Molecules 2018, 23, https://doi.org/10.3390/molecules23071760.

66. Prekodravac, J.; Vasiljević, B.; Marković, Z.; Jovanović, D.; Kleut, D.; Špitalský, Z.; Mičušik, M.; Danko, M.; Bajuk-Bogdanović, D.; Todorović-Marković, B. Green and facile microwave assisted synthesis of 
(metal-free) N-doped carbon quantum dots for catalytic applications. Ceramics International 2019, 45, 17006-17013, https://doi.org/10.1016/j.ceramint.2019.05.250.

67. Kováčová, M.; Marković, Z.; Humpolíček, P.; Micusik, M.; Švajdlenková, H.; Kleinova, A.; Danko, M.; Kubát, P.; Vajd’ák, J.; Capáková, Z.; Lehocký, M.; Münster, L.; Todorović-Marković, B.; Spitalsky, Z. Carbon Quantum Dots Modified Polyurethane Nanocomposite as Effective Photocatalytic and Antibacterial Agents. ACS Biomaterials Science and Engineering 2018, 4, 3983-3993, https://doi.org/10.1021/acsbiomaterials.8b00582.

68. Budimir, M.; Markovic, Z.; Jovanovic, D.; Vujisic, M.; Micu, M.; Danko, M.; Kleinova, A.; Svajdlenkov, H.; Spitalsk, Z.; Todorovic Markovi, B. Gamma ray assisted modification of carbon quantum dot/polyurethane nanocomposites: structural, mechanical and photocatalytic study. RSC Adv 2019, 9, 62786286, https://doi.org/10.1039/C9RA00500E.

69. Saud, P.S.; Pant, B.; Alam, A-M.; Ghouri, Z.K.; Park, M.; Kim, H.-Y. Carbon quantum dots anchored TiO nanofibers: Effective photocatalyst for waste water treatment. Ceramics International 2015, 41B, 1195311959, https://doi.org/10.1016/j.ceramint.2015.06.007.

70. Zhang, J.; Zhang, X.; Dong, S.; Zhou, X.; Dong, S. N-doped carbon quantum dots/TiO 2 hybrid composites with enhanced visible light driven photocatalytic activity toward dye wastewater degradation and mechanism insight. Journal of Photochemistry and Photobiology A: Chemistry 2016, 325, 104-110, https://doi.org/10.1016/j.jphotochem.2016.04.012.

71. Keerthana, B.G.T.; Murugakoothan, P. Synthesis and characterization of $\mathrm{CdS} / \mathrm{TiO}_{2}$ nanocomposite: Methylene blue adsorption and enhanced photocatalytic activities. Vacuum 2019, 159, 476-481, https://doi.org/10.1016/j.vacuum.2018.10.082.

72. Zhang, Y-Q.; Ma, D-K.; Zhang, Y-G.; Chen, W.; Huang, S-M. N-doped carbon quantum dots for TiO ${ }_{2}$-based photocatalysts and dye-sensitized solar cells. Nano Energy 2013, 2, 545-552, https://doi.org/10.1016/j.nanoen.2013.07.010.

73. Miao, R.; Luo, Z.; Zhong, W.; Chen, S-Y.; Jiang, T.; Dutta, B.; Nasr, Y.; Zhang, Y.; Suib, S.L. Mesoporous $\mathrm{TiO}_{2}$ modified with carbon quantum dots as a high-performance visible light photocatalyst. Applied Catalysis B: Environmental 2016, 189, 26-38, https://doi.org/10.1016/j.apcatb.2016.01.070.

74. Tian, J.; Leng, Y.; Zhao, Z.; Xia, Y.; Sang, Y.; Hao, P.; Zhan, J.; Li, M.; Liu, H. Carbon quantum dots/hydrogenated $\mathrm{TiO}_{2}$ nanobelt heterostructures and their broad spectrum photocatalytic properties under UV, visible, and near-infrared irradiation. Nano Energy 2015, 11, 419-427, https://doi.org/10.1016/j.nanoen.2014.10.025.

75. Muthulingam, S.; Lee, I-H.; Uthirakumar, P. Highly efficient degradation of dyes by carbon quantum dots $/ \mathrm{N}-$ doped zinc oxide (CQD/N-ZnO) photocatalyst and its compatibility on three different commercial dyes under daylight. J. Colloid Interface Sci. 2015, 455, 101-109, https://doi.org/10.1016/j.jcis.2015.05.046.

76. Bozetine, H.; Wang, Q.; Barras, A.; Li, M.; Hadjersi, T.; Szunerits, S.; Boukherroub, R. Green chemistry approach for the synthesis of $\mathrm{ZnO}$-carbon dots nanocomposites with good photocatalytic properties under visible light. J. Colloid Interface Sci. 2016, 465, 286-294, https://doi.org/10.1016/j.jcis.2015.12.001.

77. Zhang, X.; Pan, J.; Zhu, C.; Sheng, Y.; Yan, Z.; Wang, Y.; Feng, B. The visible light catalytic properties of carbon quantum dots/ZnO nanoflowers composites. Journal of Materials Science: Materials in Electronics 2015, 26, 2861-2866, https://doi.org/10.1007/s10854-015-2769-X.

78. Ding, D.; Lan, W.; Yang, Z.; Zhao, X.; Chen, Y.; Wang, J.; Zhang, X.; Zhang, Y.; Su, Q.; Xie, E. A simple method for preparing $\mathrm{ZnO}$ foam/carbon quantum dots nanocomposite and their photocatalytic applications. Materials Sci. Semiconductor Processing 2016, 47, 25-31, https://doi.org/10.1016/j.mssp.2016.02.004.

79. Zhang, L.; Zhang, H.; Huang, H.; Liu, Y.; Kang, Z. $\mathrm{Ag}_{3} \mathrm{PO}_{4} / \mathrm{SnO}_{2}$ semiconductor nanocomposites with enhanced photocatalytic activity and stability. New J. Chem. 2012, 36, 1541-1544, https://doi.org/10.1039/C2NJ40206H.

80. Hazarika, D.; Saikia, D.; Gupta, K.; Mandal, M.; Karak, N. Photoluminescence, Self cleaning and Photocatalytic Behavior of Waterborne Hyperbranched Polyester/Carbon dot@ $\mathrm{TiO}_{2}$ Nanocomposite. Chemistry Select 2018, 3, 6126-6135, https://doi.org/10.1002/slct.201801160.

81. Zhang, Z.; Zheng, T.; Xu, J.; Zeng, H.; Zhang, N. Carbon quantum dots/Bi $2 \mathrm{MoO}_{6}$ composites with photocatalytic $\mathrm{H}_{2}$ evolution and near infrared activity. J. Photochem Photobiol. A: Chemistry 2017, 346, 2431, https://doi.org/10.1016/j.jphotochem.2017.05.029.

82. Wang, J.; Tang, L.; Zeng, G.; Deng, Y.; Dong, H.; Liu, Y.; Wang, L.; Peng, B.; Zhang, C.; Chen, F. OD/2D interface engineering of carbon quantum dots modified $\mathrm{Bi}_{2} \mathrm{WO}_{6}$ ultrathin nanosheets with enhanced photoactivity for full spectrum light utilization and mechanism insight. Applied Catalysis B: Environmental 2018, 222, 115-123, https://doi.org/10.1016/j.apcatb.2017.10.014.

83. Kannan, R.; Kim, A.R.; Eo, S.K.; Kang, S.H.; Yoo, D.J. Facile one-step synthesis of cerium oxide-carbon quantum dots/RGO nanohybrid catalyst and its enhanced photocatalytic activity. Ceramics International 2017, 43, 3072-3079, https://doi.org/10.1016/j.ceramint.2016.11.116.

84. Liu, Y.; Yu, Y-H.; Zhang, W-D. Carbon quantum dots-doped CdS microspheres with enhanced photocatalytic performance. J. Alloys Compounds $2013, \quad 569, \quad 102-110$, https://doi.org/10.1016/j.jallcom.2013.03.202. 
85. Mukherjee, R.; Kumar, R.; Sinha, A.; Lama, Y.; Saha, A.K. A review on synthesis, characterization, and applications of nano zero valent iron (nZVI) for environmental remediation. Critical Rev. Environ. Sci. Technol. 2016, 46, 443-466, https://doi.org/10.1080/10643389.2015.1103832.

86. Dasgupta, N.; Ranjan, S.; Ramalingam, C. Applications of nanotechnology in agriculture and water quality management. Environ Chem Lett 2017, 15, 591-605, https://doi.org/10.1007/s10311-017-0648-9.

87. Karn, B.; Kuiken, T.; Otto, M. Nanotechnology and in Situ Remediation: A Review of the Benefits and Potential Risks. Environ. Health. Perspect. 2009, 117, 1823-1831, https://doi.org/10.1289/ehp.0900793.

88. Kharisov, B.I.; Dias, H.V.R.; Kharissova, O.V. Nanotechnology-based remediation of petroleum impurities from water. J. Petroleum Sci. Eng. 2014, 122, 705-718, https://doi.org/10.1016/j.petrol.2014.09.013.

89. Shahid, M.J.; AL-surhanee, A.A.; Kouadri, F.; Ali, S.; Nawaz, N.; Afzal, M.; Rizwan, M.; Ali, B.; Soliman, M.H. Role of Microorganisms in the Remediation of Wastewater in Floating Treatment Wetlands: A Review. Sustainability 2020, 12, https://doi.org/10.3390/su12145559.

90. Anawar, H.M.; Chowdhury, R. Remediation of Polluted River Water by Biological, Chemical, Ecological and Engineering Processes. Sustainability 2020, 12, https://doi.org/10.3390/su12177017.

91. Wang, L.; Wang, A. Adsorption characteristics of Congo Red onto the chitosan/montmorillonite nanocomposite. J Hazard. Mater. 2007, 147, 979-85, https://doi.org/10.1016/j.jhazmat.2007.01.145.

92. Zaghloul, A.; Ichou, A.A.; Abali, M.; Benhiti, R.; Soudani, A.; Carja, G.; Chiban, M.; Zerbet, M.; Sinan, F. A Removal and Comparative Adsorption of Anionic Dye on Various MgAl synthetic Clay. Biointerface Res. Appl. Chem. 2021, 11, 14986-14997, https://doi.org/10.33263/BRIAC116.1498614997.

93. Kassimi, A.E.; Achour, Y.; Himri, M.E.; Laamari, M.R.; Haddad, M.E. High Efficiency of Natural Safiot Clay to Remove Industrial Dyes from Aqueous Media: Kinetic, Isotherm Adsorption and Thermodynamic Studies. Biointerface Res. Appl. Chem. 2021, 11, 12717-12731, https://doi.org/10.33263/BRIAC115.1271712731.

94. Yeow, P.K.; Wong, S.W.; Hadibarata, T. Removal of Azo and Anthraquinone Dye by Plant Biomass as Adsorbent - A Review. Biointerface Res. Appl. Chem. 2021, 11, 8218-8232, https://doi.org/10.33263/BRIAC111.82188232. 